\title{
Estrogen Receptor mRNA Determined by Quantitative Real-Time PCR in the Nasal Mucosa of Women Taking Oral Contraceptives
}

\author{
Receptor ARNm de Estrógeno Determinado por PCR Cuantitativa en Tiempo \\ Real en la Mucosa Nasal de Mujeres tratadas con Anticonceptivos Orales
}

\author{
Ieda Millas ${ }^{1}$; Flávio Richeti²; Carla Sant'Anna Correa ${ }^{3}$; Mirna Duarte Barros ${ }^{4}$; \\ Rodrigo Nishihara Jorge ${ }^{5}$ \& Carlos Alberto Longui ${ }^{6}$
}

MILlAS, I.; RICHETI, F.; CORREA, C. S. A.; BARROS, M. D.; JORGE, R. N. \& LONGUI, C. A. Estrogen receptor mRNA determined by quantitative real-time pcr in the nasal mucosa of women taking oral contraceptives. Int. J. Morphol., 39(4):1147-1152, 2021.

SUMMARY: Estrogen receptors (ER) have been identified in human nasal mucosa, but its physiologic and pathologic impacts are not totally established. ER have been demonstrated in nasal mucosa by several authors, mainly by immunohistochemical method in nasal mucosa samples surgically removed. The present study aimed to quantify ER $\alpha$ and ER $\beta$ mRNA concentration by using an absolute quantitative real-time PCR in cells from nasal mucosa smear of women under oral contraceptive therapy. Nasal epithelium smear samples were collected from 110 patients divided in two groups: 55 women who present regular menstrual cycle without using contraceptives and 55 women who present regular menstrual cycle and have been using oral contraceptives for more than 3 months. All the patients answered a rhinitis symptoms questionnaire. The current study showed the potential usefulness of nasal turbinate mucosa cell sourcing, collected through swab, for extracting useful RNA for gene expression. We have identified the predominant expression of ER $\alpha$ isoform in a ratio 10-15 times higher compared to ER $\beta$ isoform. There is a tendency for positive correlation between the ERb isoform and the rhinitis severity score.

\section{KEY-WORDS: Estrogen receptors; Rhinitis; Nasal mucosa; RT-PCR}

\section{INTRODUCTION}

Estrogen receptors have been identified in human nasal mucosa, but its physiologic and pathologic impacts are not totally established. Cyclic hormonal variations during menstrual cycles and the use of oral hormonal pills seem to be influencing factors on nasal mucosa physiology, but this is still a controversial issue in the literature (Bowser \& Riederer, 2001; Zhao et al., 2001; Nappi et al., 2003; Navarrete-Palacios et al., 2003; Shirasaki et al., 2004; Wolstenholme et al., 2006; Caruso et al., 2006; Millas et al., 2011; Costa et al., 2014).

Navarrete-Palacios et al. used a cytological analysis to compare cells from nasal and vaginal smears obtained in different phases of the menstrual cycle and observed that both cell types showed similar variations dependent on the cycle phase, suggesting that cell turnover in the nasal epithelium is also influenced by the hormonal state. Nappi et al. observed in post menopause women a reduced number of seromucinous glands in the lamina propria of nasal mucosa compared with the control group at reproductive age. Caruso et al. compared nasal and vaginal mucosal smears of menopausal women with and without hormone replacement therapy and observed that both nasal and vaginal cells showed similar cytological characteristics. Wolstenholme et al. analyzed the nasal physiology by comparing clinical features and exams and did not found differences between the group using oral contraceptives and control group.

\footnotetext{
${ }^{1} \mathrm{MD}, \mathrm{PhD}$ - Otorhinolaryngologist, Professor. University Nove de Julho - UNINOVE. ORCID: 0000-0002-0102-0017.

${ }^{2} \mathrm{PhD}$ - Assistant Professor. Santa Casa SP- School of Medical Sciences. ORCID: 0000-0002-7168-4134.

${ }^{3}$ Biothecnitian. ORCID: 0000-0002-9496-2168.

${ }^{4}$ BSc, PhD - Professor Chief of Morphology Department. Santa Casa SP - School of Medical Sciences. ORCID: 0000-0002-8383-2982.

${ }^{5} \mathrm{MD}$, Otorhinolaryngologist. ORCID: 0000-0002-8443-9859.

6 MD, PhD - Full Professor. Santa Casa SP - School of Medical Sciences. ORCID: 0000-0002-6361-5235.

Institution: Molecular Medicine Laboratory, Physiology Department, Santa Casa SP - School of Medical Sciences
} 
The presence of specific estrogen receptors (ER) is required for estrogen to have its characteristic ubiquitous action in almost all tissues (Ciocca \& Roig, 1995).

There are two major isoforms: estrogen receptor alpha $(\mathrm{ER} \alpha)$ and estrogen receptor beta $(\mathrm{ER} \beta)$, which are highly specific in humans and enable selective hormonal actions in different tissues (Mosselman et al., 1996; Pavao \& Traish, 2001; Kovats, 2015).

ER have been demonstrated in nasal mucosa by several authors (Shirasaki et al.; Philpott et al., 2008; Millas et al.; Costa et al.). Bowser \& Riederer used an immunohistochemical approach to identify ER in nasal mucosa cell, detecting ER expression in the cytoplasm of cells from seromucinous glands and glandular ducts of the inferior turbinate mucosa of pregnant women. Estrogen receptors were also researched in nasal mucosa of women receiving hormonal contraceptives with symptoms of rhinitis. Nappi et al. using the same immunohistochemical method evaluated samples from the mucosa of the inferior nasal turbinate of 24 postmenopausal women: 12 with and 12 without hormonal replacement. They were able to identify both ER $\alpha$ and ER $\beta$ in cells of the glandular epithelium of the lamina propria and around venules, mainly in the group of women receiving hormonal replacement.

Shirasaki et al. studied ER expression in nasal mucosa of seven patients with rhinitis through RT-PCR method and detected the ERa in all samples studied and the ER $\beta$ in five cases.

In 2008, Philpott et al. used the immunohistochemical method on paraffin-embedded material to investigate the estrogen receptors in samples surgically removed from the inferior nasal turbinate of 25 patients with rhinitis. ER $\beta$ were detected in 24 samples in the lamina propria of the glandular epithelium and around the venules of nasal mucosa. None of the biopsies showed the presence of ER $\alpha$.

It is known that estrogen plays an important involvement in immune response of allergic diseases through specific receptors acting in some cells as: Th2, B cells, Basophilic cells and Mast cells (Fan et al., 2019).

In order to better understand the hormone action in nasal immunological processes, our previous study (Millas et al.), identified $\mathrm{ER} \alpha$ and $\mathrm{ER} \beta$ immunohistochemical staining in nasal mucosa of women with and without hormonal contraceptive treatment. Despite the specificity of immunohistochemistry, this is not a quantitative method, and therefore has the potential limitation to not recognize subtle differences in the expression of ER isoforms between groups.
The present study aimed to quantify ER $\alpha$ and ER $\beta$ mRNA concentration by using an absolute quantitative realtime PCR in cells from nasal mucosa of women under oral contraceptive therapy, allowing better recognition of the influence of estrogen on nasal mucosa physiology.

\section{MATERIAL AND METHOD}

The current study was prospectively designed and approved by the local Ethics Committee for Human Research (Comitê de Ética em Pesquisa da Faculdade de Ciências Médicas da Santa Casa de São Paulo) under number 358/09. Signed consent forms were obtained from all patients. An otolaryngologist collected swabs of the inferior turbinate mucosa through anterior rhinoscopy. All patients filled out a questionnaire about nasal symptoms and health-related quality of life (HRQL) (Juniper, 1997; Kalpaklioglu \& Baççioglu, 2008).

Only women with regular menstrual cycles were included. Exclusion criteria were as follows: the presence of acute superior airway infection, use of hormonal therapy other than that used for contraception, hormonal disorders, the use of nasal spray medications and antecedent of nasal or reproductive cancer.

Nasal epithelium smear samples from turbinates were collected from 110 volunteers. There were 55 women without recent use of oral contraceptives (Group 1) and 55 women using oral contraceptives regularly (Group 2 ) for at least 3 months. All the volunteers answered the rhinitis questionnaire and were submitted to clinical evaluation.

RNA extraction and reverse transcription reaction to cDNA for the quantification of estrogen receptors' RNAm was performed in all the samples (see casuistry and methods).

Regarding the methodological development, we have incorporated our revisers' suggestion and we have included the analysis for choosing the control genes through a geNorm spreadsheet and the selected genes were YWHAZ and CYC1.

Sample collection. The 110 samples were collected from the anterior area of inferior turbinates using a swab with a cotton edge. The material was immediately added to the preserving liquid. RNAlater ${ }^{\circledR}\left(\mathrm{n}^{\circ} \mathrm{cat} . \mathrm{AM} 7020\right.$ - Life Technology) for subsequent extraction.

RNA Extraction and reverse transcription. After extracting RNAlater ${ }^{\circledR}, 1 \mathrm{~mL}$ of TRIzol ${ }^{\circledR}\left(\mathrm{n}^{\circ}\right.$ Cat.15596-018Life Technology) was added, for cells rupture and proteins 
denaturing; then $200 \mathrm{uL}$ of chloroform was added, forming an interphase in which RNA is found in the aqueous phase; after a careful suction with pipette, we added $500 \mathrm{uL}$ of 100 $\%$ isopropanol in order to separate the RNA and then the samples were cleaned with $85 \%$ ethanol, the samples were resuspended in $40 \mathrm{uL}$ of water free from RNAse and DNAse. Next, the cDNA reverse transcription was done, following the manufacturer specifications ( $\mathrm{n}^{\circ}$ Cat. N8080234, TaqMan Reverse Transcription Reagents- Applied Biosystems).

In order to elaborate the standard curve, RNA of B15 lymphoblastic cells were extracted with a similar protocol than the one mentioned above, being only necessary to add medium centrifugation to separate the cells.

Elaborating the standard curve. The standard curve was elaborated from B-15 lymphoblastic cells cDNA in serial dilution 10:1, establishing 4 points for the curve, 4 being the most concentrated point of the curve.

PCR in real time. Initially, the best control genes for the nasal mucosal tissue were determined, using the software geNorm (Primer Desing). For application of geNorm, PCR plates were made in real time using the appropriated tagged primers (Human geNormTM kit with Perfect ProbeTM detection - Primer Desing), 10 patients and 10 controls, who had aproximate cDNA concentration, were analyzed with the genes panel offered in the kit. Calculations of deltaCt and meanQuantities were made oriented by the software protocol, and the data obtained was saved in the geNorm spreadsheet for subsequent analysis. The selected genes were YWHAZ and CYC1.

Regarding the study genes, we chose the following pre-standardized tests for the alpha and beta estrogen receptors, respectively: ESR1 Assay-Hs01046812_m1 and ESR2 Assay -Hs01100357_m1 (Life Technology).

The reactions of PCR in real time were set in a way that the same patients with the 4 genes ( 2 genes of interest and 2 control genes) would be analyzed in the same plate, all in duplicate. The reagents used in the PCR and also in their quantities were (Table I):

Table I. Rt-PCR standardized method.

\begin{tabular}{lc}
\hline Reaction reagents ESR 1 and 2 & Vol (mcL) \\
\hline Master Mix & 12.5 \\
Primer Assay & 1 \\
Water & 1.5 \\
Total & 15 \\
Reaction reagents & Vol (mcL) \\
Master Mix & 10 \\
Primer Assay & 1 \\
Water & 4 \\
Total Volume & 15 \\
\hline
\end{tabular}

The reaction cycle of $\mathrm{PCR}$ in real time was standardized in: $50{ }^{\circ} \mathrm{C}$ for 2 minutes, $95^{\circ} \mathrm{C}$ for 10 minutes, 40 cycles of $95^{\circ} \mathrm{C}$ for 15 seconds and $60^{\circ} \mathrm{C}$ for 1 minute, as per the previously established protocol by the team.

\section{RESULTS}

The individual results of patients without oral contraceptives (Group 1) and with oral contraceptives (Group 2 ) are described in the appendixes 1 and 2, respectively.

When both groups were compared, there was no difference between the chronological ages or between the rhinitis score (Table II).

Table II. Comparison of rhinitis score of patients without and with oral contraception use.

\begin{tabular}{lccc}
\hline & $\begin{array}{c}\text { Group 1 } \\
\mathrm{n}=51\end{array}$ & $\begin{array}{c}\text { Group 2 } \\
\mathrm{n}=51\end{array}$ & $\mathrm{P}$ \\
\hline Age average - years & 29.4 & 27.1 & \multirow{2}{*}{0.08} \\
(DP) & $(7.2)$ & $(6.4)$ & \\
A verage rhinitis score & 42.7 & 47.2 & 0.15 \\
(DP) & $(16.8)$ & $(16.1)$ & \\
\hline
\end{tabular}

Regarding the sourcing of appropriate RNA for expression evaluation, we note that the material offered by swab was sufficient to identify the control genes in $51 / 55$ patients from the Group 1 and in 51/55 patients from the Group 2.

Appropriate amplification of the ER $\alpha$ gene was detected in 27/51 patients from Group 1 and in 27/51 patients from Group 2, suggesting that despite the efficiency of collecting cells through nasal swab, the amount of material is relatively low, with the expression of ER $\alpha$ being significantly detectable in around $50 \%$ of individuals, regardless of oral contraceptive use. This shows that in relation to the control genes, ER $\alpha$ expression is relatively low, needing a larger amount of cells for its appropriate detection.

The expression values of the ER $\alpha$ isoform, in 27 patients from each group, were corrected by the control genes CYC1 and YWHAZ, as described on Table III. There was no difference in $\mathrm{ER} \alpha$ expression when both groups were compared.

Table III. Expression values of the ER $\alpha$ isoform, on groups with and without oral contraceptives.

\begin{tabular}{lccc}
\hline & $\begin{array}{c}\text { Group 01 } \\
\text { Average (DP) } \\
\mathrm{n}=27\end{array}$ & $\begin{array}{c}\text { Group 02 } \\
\text { Average (DP) } \\
\mathrm{n}=27\end{array}$ & $\mathrm{P}$ \\
\hline $\mathrm{ER} \alpha / \mathrm{CYC1} 1$ & $7.9(1.8)$ & $8.2(2.6)$ & 0.55 \\
$\mathrm{ER} \alpha /$ YWHAZ & $9.1(4.5)$ & $10.3(7.0)$ & 0.30 \\
\hline
\end{tabular}


The ER $\beta$ gene expression was detectable in a lower number of individuals: 15/51 patients from group 1 and in 19/ 51 patients from Group 2. Table IV summarizes the findings in which both ER $\alpha$ and ER $\beta$ isoforms were detectable, showing the expression correlation between both isoforms.

Table IV. Relative expression values between ER $\alpha$ and ER $\beta$ isoforms, in groups with and without oral contraceptives.

\begin{tabular}{lcc}
\hline & Group 1 & Group 2 \\
& $\begin{array}{c}\text { Average } \\
\mathrm{n}=15\end{array}$ & $\begin{array}{c}\text { Average } \\
\mathrm{n}=19\end{array}$ \\
\hline Relation: Ct ER $\alpha$ / Ct ER $\beta$ & $0.90(0.04)$ & $0.88(0.04)$ \\
Difference: Ct ER $\alpha$ - Ct ER $\beta$ & $3.8(1.6)$ & $4.4(1.7)$ \\
\hline
\end{tabular}

The ratio ER $\alpha / E R \beta$ was similar between groups 1 and 2. The average difference between the ER $\alpha$ e ER $\beta$ isoforms' Cts was 4,1 ; this means that if we consider as equivalent both isoforms' amplification efficiency, the $4 \mathrm{Cts}$ difference is the equivalent of a ER $\beta$ isoform concentration approximately 10 to 15 times smaller than the ER $\alpha$ isoform concentration.

The analysis of correlations between the many variables of the study was absent when the chronological age and the ER $\alpha$ isoform expression were correlated to the rhinitis score, in separate or combined groups.

A relevant finding was observed in patients who expressed the $\operatorname{ER} \beta(n=34)$ isoform. In this subset, there was a tendency for positive correlation between the ER $\beta$ isoform expression and the rhinitis score (Fig. $1 ; \mathrm{R}=0.27 ; \mathrm{P}=0.09$ ). In this statistical analysis, the test power was low and showed the need of a $\mathrm{n}=50$ in order to reach a significant correlation by keeping the same parameters.

\section{DISCUSSION}

The inferior turbinate mucosa is responsible for important functions related to breath and immunological defense. Changes in nasal symptoms have been associated with hormone receptor alterations, but some aspects of this correlation are still controversial (Bowser \& Riederer; Nappi et al.; Navarrete-Palacios et al.; Wolstenholme et al.; Caruso et al.; Philpott et al.).

Estrogen action has been studied in several tissues not related to reproduction, such as lung, central nervous system and eyes. Most of the non-reproductive estrogen effects are related to improve the cellular growth and glandular secretions (Ciocca \& Roig; Zhao et al.; FuchsjägerMayrl et al., 2002; Simoncini et al., 2002; Välimaa et al.,

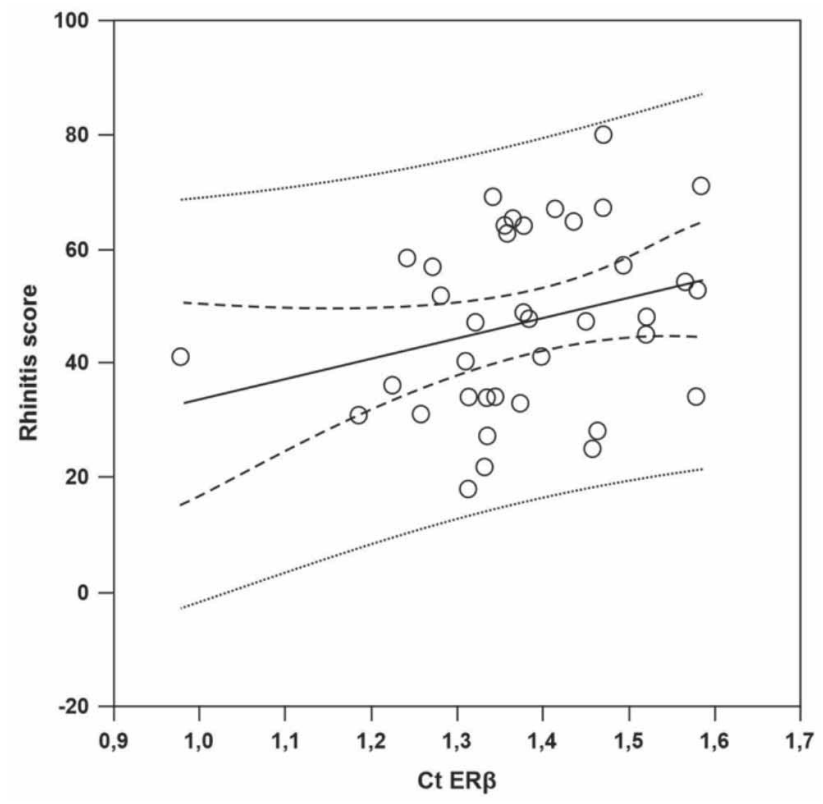

Fig. 1. Correlation between ER $\beta$ expression and rhinitis score in 34 patients, regardless of the use of oral contraceptives

2004; Beier et al., 2005; Tang et al., 2008; Ivanova et al., 2009; Watanabe et al., 2019).

The studies in otorhinolaryngology have recognized improved cytological trophic characteristics in cells of the nasal mucosa submitted to higher estrogen levels. Also, some nasal clinical symptoms were related to hormonal status such as the use of contraceptive pills or menopause (Nappi et al.; Navarrete-Palacios et al.; Wolstenholme et al.; Caruso et al.; Philpott et al.).

The presence of specific estrogen receptors is required for estrogen to have its characteristic ubiquitous action in almost all tissues. ER $\alpha$ and $E R \beta$ are the isoforms of estrogen that enable high specificity and selective hormonal balance in different tissues (Kovats). So, this study showed the absolute quantity of these two isoforms in women under different hormonal conditions.

Our findings showed the predominant expression of $\mathrm{ER} \alpha$ isoform compared to ER $\beta$ isoform, regardless of the use of oral contraception. Only ER $\beta$ isoform was positively correlated with the rhinitis score shown by patients. These findings are compatible with the results obtained in a previous study of our group, which confirmed the significant expression of ER $\beta$ isoform evaluated before (Millas et al.).

Considering that the estrogen receptors support the specific hormone action in the target tissues, future studies 
are necessary to identify the required expression level of $\mathrm{ER} \beta$ or ER $\alpha$ isoform in order to define the relationship between estrogen and its activity in the nasal mucosa.

The ERs and their different mechanisms of action have a relevant role in the immune response, modulating inflammatory processes, especially those related to the respiratory mucosa (Kovats; Fan et al.). Many studies on the activation and expression of the ERs, with the aim of understanding the clinical aspects and therapeutic pathways, are breaking on the current scenario.

\section{CONCLUSION}

The current study showed the potential usefulness of nasal turbinate mucosa cell sourcing, collected through swab, for extracting useful RNA for gene expression.

We have identified the predominant expression of $E R \alpha$ isoform in a ratio 10-15 times higher compared to ER $\beta$ isoform.

There was no statistical difference between patients of Group 01 and 02 in this present study.

There is a tendency for positive correlation between the ER $\beta$ isoform and the rhinitis severity score $(r=0.27$; $\mathrm{p}=0.09$ ).

MILLAS, I.; RICHETI, F.; CORREA, C. S. A.; BARROS, M. D.; JORGE, R. N. \& LONGUI, C. A. Receptor ARNm de estrógeno determinado por per cuantitativa en tiempo real en la mucosa nasal de mujeres tratadas con anticonceptivos orales. Int. J. Morphol., 39 (4):1147-1152, 2021.

RESUMEN: Se han identificado receptores de estrógeno (RE) en la mucosa nasal humana, sin embargo sus impactos fisiológicos y patológicos aún no están totalmente establecidos. Varios autores han demostrado RE en la mucosa nasal, principalmente por método inmunohistoquímico en muestras obtenidas quirúrgicamente. El presente estudio tuvo como objetivo cuantificar la concentración de ARNm de REa y REb mediante el uso de una PCR cuantitativa absoluta en tiempo real en células de frotis de mucosa nasal de mujeres bajo terapia anticonceptiva oral. Se recolectaron muestras de frotis de epitelio nasal de 110 pacientes divididas en dos grupos: 55 mujeres que presentan ciclo menstrual regular sin uso de anticonceptivos y 55 mujeres que presentan ciclo menstrual regular con uso de anticonceptivos orales durante más de 3 meses. Todas las pacientes respondieron un cuestionario de síntomas de rinitis. El estudio actual mostró la utilidad de la obtención de células de la mucosa de la concha nasal, recolectadas a través de un hisopo, para extraer ARN para la expresión génica.
Hemos identificado la expresión predominante de la isoforma RE $\mu$ en una proporción de 10 a 15 veces mayor en comparación con la isoforma REß. Hemos identificado la expresión predominante de la isoforma RE $\alpha$ en una proporción de 10 a 15 veces mayor en comparación con la isoforma REß. Existe una tendencia a una correlación positiva entre la isoforma REß y la puntuación de gravedad de la rinitis.

PALABRAS CLAVE: Receptores de estrógenos; Rinitis; Mucosa nasal; RT-PCR

\section{REFERENCES}

Beier, K.; Ginez, I. \& Schaller, H. Localization of steroid hormone receptors in the apocrine sweat glands of the human axilla. Histochem. Cell Biol., 123(1):61-5, 2005.

Bowser, C. \& Riederer, A. Detection of progesterone receptors in connective tissue cells of the lower nasal turbinates in women. Laryngorhinootologie, 80(4):182-6, 2001.

Caruso, S.; Serra, A.; Maiolino, L.; Agnello, C.; Di Mari, L.; Ruta, S.; Arcidiacono, A. \& Cianci, A. Cytological aspects of the nasal respiratory epithelium in reproductive-age women taking oral contraceptives. Eur. J. Contracept. Reprod. Health Care, 11(4):2507, 2006.

Ciocca, D. R. \& Roig, L. M. Estrogen receptors in human nontarget tissues: biological and clinical implications. Endocr. Rev., 16(1):35$62,1995$.

Costa, H. O.; de Castro Neto, N. P.; Rossi, L. M.; Millas, I.; Coelho, F. \& da Silva, L. Influence of estradiol administration on estrogen receptors of nasal mucosa: an experimental study on guinea pigs. Braz. J. Otorhinolaryngol., 80(1):18-23, 2014.

Fan, Z.; Che, H.; Yang, S. \& Chen, C. Estrogen and estrogen receptor signaling promotes allergic immune responses: Effects on immune cells, cytokines, and inflammatory factors involved in allergy. Allergol. Immunopathol. (Madr.), 47(5):506-12, 2019.

Fuchsjäger-Mayrl, G.; Nepp, J.; Schneeberger, C.; Sator, M.; Dietrich, W.; Wedrich, A.; Huber, J. \& Tschugguel, W. Identification of estrogen and progesterone receptor mRNA expression in the conjunctiva of premenopausal women. Invest. Ophthalmol. Vis. Sci., 43(9):2841-4, 2002.

Ivanova, M. M.; Mazhawidza, W.; Dougherty, S. M.; Minna, J. D. \& Klinge, C. M. Activity and intracellular location of estrogen receptors alpha and beta in human bronchial epithelial cells. Mol. Cell. Endocrinol., 305(1-2):12-21, 2009.

Juniper, E. F. Quality of life in adults and children with asthma and rhinitis. Allergy, 52(10):971-7, 1997.

Kalpaklioglu, A. F. \& Baççioglu, A. Evaluation of quality of life: impact of allergic rhinitis on asthma. J. Investig. Allergol. Clin. Immunol., 18(3):168-73, 2008.

Kovats, S. Estrogen receptors regulate innate immune cells and signaling pathways. Cell. Immunol., 294(2):63-9, 2015.

Millas, I.; Liquidato, B. M.; Buck, H. de S.; Barros, M. D.; Paes, R. A. P. \& Dolci, J. E. L. Evaluation of estrogenic receptors in the nasal mucosa of women taking oral contraceptives. Contraception, 83(6):5717, 2011.

Mosselman, S.; Polman, J. \& Dijkema, R. ER beta: identification and characterization of a novel human estrogen receptor. FEBS Lett., 392(1):49-53, 1996.

Nappi, C.; Di Spiezio Sardo, A.; Guerra, G.; Bifulco, G.; Testa, D. \& Di Carlo, C. Functional and morphologic evaluation of the nasal mucosa before and after hormone therapy in postmenopausal women with nasal symptoms. Fertil. Steril., 80(3):669-71, 2003. 
Navarrete-Palacios, E.; Hudson, R.; Reyes-Guerrero, G. \& GuevaraGuzmán, R. Correlation between cytological characteristics of the nasal epithelium and the menstrual cycle. Arch. Otolaryngol. Head Neck Surg., 129(4):460-3, 2003.

Pavao, M. \& Traish, A. M. Estrogen receptor antibodies: specificity and utility in detection, localization and analyses of estrogen receptor alpha and beta. Steroids, 66(1):1-16, 2001.

Philpott, C. M.; Wild, D. C.; Wolstensholme, C. R. \& Murty, G. E. The presence of ovarian hormone receptors in the nasal mucosa and their relationship to nasal symptoms. Rhinology, 46(3):221-5, 2008.

Shirasaki, H.; Watanabe, K.; Kanaizumi, E.; Konno, N.; Sato, J.; Narita, S. I. \& Himi, T. Expression and localization of steroid receptors in human nasal mucosa. Acta Otolaryngol., 124(8):958-63, 2004.

Simoncini, T.; Fornari, L.; Mannella, P.; Varone, G.; Caruso, A.; Liao, J. K. \& Genazzani, A. R. Novel non-transcriptional mechanisms for estrogen receptor signaling in the cardiovascular system. Interaction of estrogen receptor alpha with phosphatidylinositol 3-OH kinase. Steroids, 67(12):935-9, 2002.

Tang, X.; Meng, H.; Han, J.; Zhang, L.; Hou, J. \& Zhang, F. Up-regulation of estrogen receptor-beta expression during osteogenic differentiation of human periodontal ligament cells. J. Periodontal. Res., 43(3):311$21,2008$.

Välimaa, H.; Savolainen, S.; Soukka, T.; Silvoniemi, P.; Mäkelä, S.; Kujari, H.; Gustafsson, J. A. \& Laine, M. Estrogen receptor-beta is the predominant estrogen receptor subtype in human oral epithelium and salivary glands. J. Endocrinol., 180(1):55-62, 2004.

Watanabe, Y.; Tajiki-Nishino, R.; Tajima, H. \& Fukuyama, T. Role of estrogen receptors $\mathrm{a}$ and $\mathrm{b}$ in the development of allergic airway inflammation in mice: A possible involvement of interleukin 33 and eosinophils. Toxicology, 411:93-100, 2019.

Wolstenholme, C. R.; Philpott, C. M.; Oloto, E. J. \& Murty, G. E. Does the use of the combined oral contraceptive pill cause changes in the nasal physiology in young women? Am. J. Rhinol., 20(2):238-40, 2006.

Zhao, X. J.; McKerr, G.; Dong, Z.; Higgins, C. A.; Carson, J.; Yang, Z. Q. \& Hannigan, B. M. Expression of oestrogen and progesterone receptors by mast cells alone, but not lymphocytes, macrophages or other immune cells in human upper airways. Thorax, 56(3):205-11, 2001.

\section{Corresponding author: \\ leda Millas \\ MD, PhD, Professor \\ Otorhinolaryngologist \\ University Nove de Julho \\ UNINOVE \\ BRAZIL}

E-mail: iedamillas@uol.com.br

ORCID: 0000-0002-0102-0017

Received: 21-04-2021

Accepted: 30-05-2021 